\title{
Carbohydrate status in patients with phenylketonuria
}

\author{
María L. Couce ${ }^{1 *}$ (D), Paula Sánchez-Pintos ${ }^{1}$, Isidro Vitoria², María-José De Castro ${ }^{1}$, Luís Aldámiz-Echevarría ${ }^{3}$, \\ Patricia Correcher ${ }^{2}$, Ana Fernández-Marmiesse ${ }^{1}$, Iria Roca', Alvaro Hermida', Miguel Martínez-Olmos ${ }^{1}$ \\ and Rosaura Leis ${ }^{4}$
}

\begin{abstract}
Background: In patients with phenylketonuria (PKU), a low-phenylalanine (Phe) diet supplemented with lowprotein foods and a Phe-free amino acid mixture favors a dietary intake rich in carbohydrates, but little is known about how these molecules are metabolized in this setting. The objective of the present study was to analyze carbohydrate metabolism in patients with hyperphenylalaninemia.

Methods: We conducted a multicenter cross-sectional study to investigate biochemical markers of basal and postprandial carbohydrate metabolism in PKU patients according to age, Phe tolerance, waist circumference and body mass index (BMI), diet, tetrahydrobiopterin (BH4) supplementation, and adherence to treatment. Basal biomarkers and anthropometric parameters were also evaluated in patients with mild hyperphenylalaninemia (MHPA) and in healthy controls.

Results: A total of 83 patients aged $4-52$ years were studied; $68.7 \%$ had PKU and 31.3\% had MHPA. 68 healthy controls of similar sex and age were also evaluated Metabolic control was adequate in $71.9 \%$ of PKU patients. Fasting glucose levels (mean $80.77 \pm 8.06 \mathrm{mg} / \mathrm{dL}$ ) were high in just one patient, but fasting insulin levels, with a mean of $12.74 \pm 8.4 \mathrm{mlU} / \mathrm{L}$, were altered in $15 \mathrm{PKU}$ patients (26.3\%) and markedly higher than in patients with MPHA ( $p=0.035)$. Fasting insulin levels and Homeostasis Model Assessment Insulin Resistance (HOMA-IR) were significantly higher than in healthy controls and correlated with body mass index, waist circumference, age, and also showed statistically significant differences according to diagnosis and Phe tolerance $(p<0.05)$. Patients under BH4 therapy had lower insulin levels and HOMA-IR. A higher mean carbohydrate intake from AA mixtures was observed in classic PKU patients. The caloric intake in the form of carbohydrates was also higher in PKU than MHPA patients $(p=0.038)$ and it was correlated with basal insulin ( $r h o=0.468, p=0.006), \operatorname{HOMA}-\mathrm{IR}(\mathrm{rho}=0.423, p=0.02)$, BMI (rho 0.533, $p=0.002$ ), and waist circumference (rho 0.584, $p=0.0007$ ).

Conclusions: This study shows that PKU patients are at risk of carbohydrate intolerance and insulin resistance, more evident in adults and overweight patients, probably related to their higher caloric intake in form carbohydrate content. A higher dependency of AA mixtures was demonstrated in PKU patients.
\end{abstract}

Keywords: HOMA index, Insulin, Nutrition, Phenylalanine, Tetrahydrobiopterin

\footnotetext{
* Correspondence: maria.luz.couce.pico@sergas.es

${ }^{1}$ Unit of Diagnosis and Treatment of Congenital Metabolic Diseases, S.

Neonatology, Department of Pediatrics, Hospital Clínico Universitario de

Santiago de Compostela, CIBERER, Health Research Institute of Santiago de

Compostela (IDIS), A Choupana, s/n, 15706 Santiago de Compostela, A

Coruña, Spain

Full list of author information is available at the end of the article
}

(c) The Author(s). 2018 Open Access This article is distributed under the terms of the Creative Commons Attribution 4.0 International License (http://creativecommons.org/licenses/by/4.0/), which permits unrestricted use, distribution, and reproduction in any medium, provided you give appropriate credit to the original author(s) and the source, provide a link to the Creative Commons license, and indicate if changes were made. The Creative Commons Public Domain Dedication waiver (http://creativecommons.org/publicdomain/zero/1.0/) applies to the data made available in this article, unless otherwise stated. 


\section{Introduction}

Phenylketonuria (PKU) is an autosomal recessive disorder of phenylalanine (Phe) metabolism caused by deficient activity of the hepatic enzyme L-phenylalanine4-hydroxylase (PAH, EC 1.14.16.1) due to variations in the PAH gene (NM 000277.1) (OMIM 261600). The estimated overall incidence of PKU in Caucasians is 1 case in every 10,000 live births [1]. PKU is usually detected by newborn screening, enabling early diagnosis and treatment and consequently prevention of serious, irreversible neurological sequelae. Treatments aimed at maintaining optimal serum Phe concentrations include dietary treatment and a synthetic form of tetrahydrobiopterin (BH4) in patients who respond to the $\mathrm{BH} 4$ loading test [2-4]. Most patients, however, receive dietary treatment only [5]. The standard PKU diet is a low-Phe diet, which consists of restricted natural protein intake supplemented with special low-protein foods and a Phe-free amino acid mixture (AA mixture). Although dietary treatment has been used in PKU for over 50 years, its metabolic impact remains to be optimized [6-8]. There has been increasing interest in improving the nutritional profile of AA mixtures to ensure nutritional adequacy and optimal growth $[7,9,10]$. Moreover, the nutritional profile of these mixtures varies considerably from one product to the next [11] and this is something that needs to be addressed if long-term outcomes are to be improved. Altered micronutrient status [9], vitamin deficiencies [12] and an atherogenic lipid profile in individuals with excess weight [13] have all been described in PKU.

Despite the risks associated with high carbohydrate intake, little research has been done on carbohydrate metabolism in patients with PKU. According to one recent study, children with PKU consumed more carbohydrates (\% of total energy) than healthy controls with a higher dietary glycemic index [14]. The authors claimed that the restriction of natural proteins favors, and might even physiologically stimulate, the consumption of foods rich in carbohydrates (in particular, simple carbohydrates), leading to a higher glycemic index diet. PKU patients are thus vulnerable to metabolic abnormalities and excess weight [15].

Patients who adhere to dietary recommendations appear to have similar cardiovascular risks to the healthy population [16]. However, risk factors such as an atherogenic lipid profile, elevated blood pressure, and high-sensitivity C-reactive protein concentrations have been reported in overweight or obese patients with PKU [13]. Considering the shortage (and small size) of studies analyzing carbohydrate metabolism in patients with PKU $[14,15,17,18]$, we undertook a cross-sectional study of children and adults with PKU from three Spanish hospitals to analyze biochemical markers of basal and postprandial carbohydrate metabolism according to Phe tolerance, age, waist circumference (WC), body mass index (BMI), diet, $\mathrm{BH} 4$ supplementation, and adherence to treatment. We also analyzed the potential role of ghrelin and HOMA-IR as cardiometabolic risk factors in this population.

\section{Patients and methods \\ Study design}

This was a cross-sectional observational study conducted from February 2016 to April 2017Written informed consent was obtained from all patients or from parents or legal guardians in the case of children $<16$ years of age. The population comprised patients diagnosed with PKU at three Spanish hospitals. All the patients were monitored using the same protocol at their respective hospital. Patients were diagnosed through newborn screening (introduced for PKU in Spain in the 1970s-1980s) or clinical suspicion. Exclusion criteria were poor medical monitoring, changes to AA mixture in the month prior to inclusion in the study, and pregnancy. A control group of 68 healthy cases, paired by age and sex, were also included.

\section{Parameters}

The following parameters were evaluated: age (adults vs. patients $\leq 18$ years); sex; phenotype (mild hyperphenylalaninemia [MHPA] [serum Phe level 120-360 $\mu \mathrm{mol} / \mathrm{L}$ at diagnosis], mild-moderate PKU [MPKU] [360-1200 $\mu \mathrm{mol} /$ L], or classic PKU [CPKU] [> $1200 \mu \mathrm{mol} / \mathrm{L}]$ according to US guidelines [19]); disease detection (early vs. late diagnosis); annual median blood Phe levels (target levels of 120$360 \mu \mathrm{mol} / \mathrm{L}$ for children $<12$ years and $120-600 \mu \mathrm{mol} / \mathrm{L}$ for older patients as established in Spanish recommendations published in 2014 [20], which are also congruent with the most recent European guidelines for PKU [21]); carbohydrate content in AA mixture; HOMA-IR; anthropometric data (weight, height, WC, and BMI), Phe tolerance (low < $500 \mathrm{mg}$ /day vs. high $>500 \mathrm{mg} /$ day); $6 \mathrm{R}^{-\mathrm{BH}_{4}}$ therapy (yes vs. no). We also assessed the following blood biochemical markers: glucose, insulin, plasma amino acids (Phe, tyrosine, alanine, valine, leucine, isoleucine, and threonine), C-peptide, urea, ghrelin, insulin-like growth factor 1 (IGF1), IFG-binding protein 3 (IGFBP3), lactate, pyruvate, and fructosamine (this parameter was only was evaluated in one center). Metabolic control, or dietary adherence, was evaluated using median blood Phe levels for the last year and the pre-established "safe" thresholds for each age group (see above). Basal blood samples were collected at the same time each day (at 9:00 after overnight fasting) in all patients and 120 min after ingestion of the adjusted AA mixture in the case of patients with MPKU and CPKU. Blood was not collected during infections or treatment with medication other than $6 \mathrm{R}-\mathrm{BH}_{4}$. Questions about these aspects were 
formulated prior to taking samples. The reference ranges for the biochemical markers were as follows: glucose $(74-105 \mathrm{mg} / \mathrm{dL})$, insulin (1.5-18.5 $\mathrm{mIU} / \mathrm{L})$, peptide C $(0.81-2.85 \mathrm{ng} / \mathrm{mL})$, urea $(13-50 \mathrm{mg} / \mathrm{dL})$, ghrelin (520-700 $\mathrm{pg} / \mathrm{mL})$, IGF1 (66-249 $\mathrm{mg} / \mathrm{mL})$, IGFBP3 $(3-7 \mu \mathrm{g} / \mathrm{mL})$, lactate $(0.63-2.44 \mathrm{mmol} / \mathrm{L})$, pyruvate $(0.033-0.077 \mathrm{mmol} / \mathrm{L})$, and fructosamine (151-300 $\mu \mathrm{mol} / \mathrm{L})$.

\section{Methods}

The three hospitals followed the same protocol. Dietary treatment was based on Spanish PKU guideline recommendations [22] and consisted of restricted natural protein intake supplemented with an AA mixture. Mean protein intake was 1.3-1.5 times higher than recommended dietary allowances [23]. The AA mixture was taken three or four times a day, with one-third of the total dose being taken in the morning. The diet was assessed weekly using 3-day food surveys completed online (www.odimet.es). Patients with MHPA at diagnosis did not require treatment and followed a normal diet.

Standing height was measured using a wall-mounted stadiometer and patients were weighed (barefoot and after overnight fasting) to the nearest $100 \mathrm{~g}$ on a digital scales. Nutritional status according to BMI was calculated as weight $(\mathrm{kg}) /$ height $^{2}\left(\mathrm{~m}^{2}\right)$. Patients $>18$ years of age were classified according to the WHO criteria into four categories: underweight (BMI < 18.5), normal weight (BMI 18.5-24.99), overweight (BMI 25-29.99), and obese $(B M I \geq 30)$. Younger patients were classified using the WHO Child Growth Standards as underweight (BMI <15th percentile), normal weight (BMI 15-85th percentile), overweight (BMI 85-95th percentile), or obese (BMI >95th percentile) $[24,25]$.

WC was measured in centimeters midway between the lower rib margin and the iliac crest. In the case of children, WC measurements were stratified by sex and age following the method described in the Galinut Study [26]. For adults, specific WC values from the International Diabetes Federation were used [27].

HOMA-IR was calculated using the Matthews formula [28]: insulin $(\mu \mathrm{U} / \mathrm{mL})^{*}$ [glucose $\left.\left.(\mathrm{mmol} / \mathrm{L})\right] / 22.5\right]$, with a score $\geq 2.5$ indicating insulin resistance [29]. Insulin resistance was also assessed using the quantitative insulin sensitivity check index (QUICKI): $1 / \log 10$ basal insulin $(\mathrm{uIU} / \mathrm{mL})+\log 10$ basal glucose $(\mathrm{mg} / \mathrm{dL})$ [30] . Glucose, urea, and fructosamine levels were measured by colorimetric enzymatic analysis (ADVIA 2400, Siemens) and lactate and pyruvate were measured using a quantitative Trinder method assay (BEN S.r.l). Serum insulin and C-peptide levels were measured using the ADVIA Centaur XP immunoassay system (Siemens), while IG 1 and IGFBP3 were measured using the chemiluminescence IMMULITE $2000 \mathrm{im}$ munoassay system (Siemens). Total serum ghrelin was determined by radioimmunoassay (Ghrelin Total RIA Kit, Linco Research). Quantitative analysis of plasma amino acids was performed using ion-exchange chromatography (Biochrom 30 Amino Acid Analyzer) after deproteinization of samples with 5-sulfosalicylic acid.

\section{Statistical analysis}

To determine significant associations and/or differences between the study variables, we first used the Kolmogorov-Smirnov and Shapiro-Wilk tests to check for normal distribution. In cases where one of the variables was quantitative and the other qualitative, we applied the Student t-test or ANOVA if the quantitative variable was normally distributed, and the Wilcoxon signed-rank test or the Kruskal-Wallis test otherwise. The Fisher exact test was used when both variables were qualitative. To assess correlations between quantitative variables, we used Pearson's correlation for normally distributed data and Spearman's rho otherwise. The resulting $p$ values were adjusted using the Benjamini-Hochberg procedure and only values lower than 0.05 were considered significant. To evaluate interdependencies between variables a stepwise regression method based on AIC (Aikake Information Criterion) was used; the adjusted model was a multiple or linear regression when the response variable was quantitative, and a logistic regression model for two-level qualitative variables. Statistical analysis was performed using R Core Team (2017), version 3.4.1. [31]

\section{Results}

Eighty-three patients ( $40.96 \%$ male; age range $4-52$ years; $48.2 \%$ adults) were included in the study. Of these, 57 (68.7\%) had PKU and 26 (31.3\%) had MHPA. PKU was classified as CPKU group in 37 patients (64.9\%) and as MPKU in 20 (35.1\%). Seventy patients (84.3\%) were diagnosed through newborn screening. Ten patients (17.5\%) with PKU received $10-20 \mathrm{mg} / \mathrm{kg} /$ day of $6 \mathrm{R}-\mathrm{BH} 4$ therapy and all of them also received dietary treatment but relaxed (Table 1). In the control group there were no differences of sex $(45.6 \%$ males, $p=0.85)$ or age (mean: $19.34 \pm 12.45 ; p=0.27$ ).

Adequate metabolic control was observed in 41 (71.9\%) of the 57 PKU patients over the observation period; in 18 (54.5\%) of the 33 adult PKU patients, and in $100 \%$ of those who received $6 \mathrm{R}-\mathrm{BH} 4$ treatment. In the overall group, BMI was above the upper limit in 32 patients (38.6\%), $75 \%$ of whom were overweight and $25 \%$ of whom were obese. Thirty-two patients $(38.6 \%)$ had WC values above the upper limit ( $>95$ th percentile in 10 cases). Compared with the MPHA group, a significantly higher proportion of patients in the PKU group had BMI and WC above the upper limit $(87.5 \%$ vs. $12.5 \%$, 
Table 1 Characteristics of patients according to type of diagnosis

\begin{tabular}{|c|c|c|c|c|c|}
\hline \multirow[t]{2}{*}{ Variables } & \multicolumn{3}{|c|}{ Type of diagnosis } & \multirow[t]{2}{*}{$p^{1}$} & \multirow[t]{2}{*}{$p^{2}$} \\
\hline & $\overline{\mathrm{CPKU}}$ & MPKU & MHPA & & \\
\hline Patients N & 37 & 20 & 26 & & \\
\hline Age (y) & $24.92 \pm 11.64$ & $16.7 \pm 7.26$ & $13.23 \pm 10.24$ & 0.002 & 0.0006 \\
\hline $\operatorname{Sex}(F / M)$ & $19 F / 18 M$ & $13 \mathrm{~F} / 7 \mathrm{M}$ & $17 \mathrm{~F} / 9 \mathrm{M}$ & 0.48 & 0.47 \\
\hline $\mathrm{TD}(\mathrm{E} / \mathrm{L})$ & $27 \mathrm{E} / 10 \mathrm{~L}$ & $18 \mathrm{E} / 2 \mathrm{~L}$ & $25 \mathrm{E} / 1 \mathrm{~L}$ & 0.38 & 0.26 \\
\hline Treatment $(D / P+D)$ & $36 \mathrm{D} / 1 \mathrm{P}+\mathrm{D}$ & $11 D / 9 P+D$ & - & - & - \\
\hline $\begin{array}{l}\mathrm{BMl} \\
\left(\mathrm{kg} / \mathrm{m}^{2}\right)\end{array}$ & $\begin{array}{l}25.57 \pm 5.96 \\
15 \mathrm{Nor} / 22 \uparrow\end{array}$ & $\begin{array}{l}22.12 \pm 5.78 \\
14 \text { Nor } / 6 \uparrow\end{array}$ & $\begin{array}{l}18.46 \pm 3.79 \\
22 \mathrm{Nor} / 4 \uparrow\end{array}$ & 0.0003 & 0.0004 \\
\hline $\begin{array}{l}\text { WC } \\
(\mathrm{cm})\end{array}$ & $\begin{array}{l}87.08 \pm 17.42 \\
13 \mathrm{Nor} / 24 \uparrow\end{array}$ & $\begin{array}{l}73.96 \pm 13.92 \\
16 \mathrm{Nor} / 4 \uparrow\end{array}$ & $\begin{array}{l}64.85 \pm 11.59 \\
22 \mathrm{Nor} / 4 \uparrow\end{array}$ & 0.002 & 0.001 \\
\hline Phe median inter- quartile range $(\mu M)$. & 484(378-840) & $241.9(205-482)$ & $295.5(246-310)$ & 0.007 & $3.2 e^{-05}$ \\
\hline Phe tol (mg/day) & $379 \pm 148.57$ & $868.9 \pm 682.53$ & Free diet- & - & - \\
\hline Glucose (mg/dL) & $81.24 \pm 9.76$ & $78.05 \pm 4.12$ & $82.19 \pm 7.4$ & 0.29 & 0.29 \\
\hline Insuline (mUI/L) & $16.22 \pm 10$ & $11.12 \pm 5.72$ & $9.03 \pm 5.34$ & 0.035 & 0.02 \\
\hline Peptide C (ng/mL) & $2.3 \pm 1.03$ & $1.54 \pm 0.78$ & $1.31 \pm 0.72$ & 0.028 & 0.002 \\
\hline Urea $(\mathrm{mg} / \mathrm{dL})$ & $21.86 \pm 6.14$ & $23.3 \pm 6.36$ & $26.15 \pm 6.58$ & 0.18 & 0.31 \\
\hline Fructosamine $(\mu \mathrm{M})$ & $234.25 \pm 44.36$ & $222.8 \pm 25.2$ & $232.65 \pm 32.74$ & 0.7 & 0.28 \\
\hline Lactate (mM) & $1.28 \pm 0.61$ & $1.01 \pm 0.49$ & $1.29 \pm 0.65$ & 0.45 & 0.31 \\
\hline IGF-1 (mg/mL) & $204.77 \pm 77.7$ & $227.89 \pm 112.34$ & $193.35 \pm 125.69$ & 0.11 & 0.22 \\
\hline IGF-BP3 $(\mu \mathrm{g} / \mathrm{mL})$ & $4.68 \pm 1.2$ & $4.65 \pm 1.39$ & $4.39 \pm 0.97$ & 0.34 & 0.62 \\
\hline Ghrelin (pg/mL) & $884.94 \pm 454.91$ & $687.5 \pm 319.34$ & $977 \pm 517.78$ & 0.16 & 0.25 \\
\hline HOMA-IR & $3.35 \pm 2.26$ & $2.17 \pm 1.17$ & $1.88 \pm 1.19$ & 0.034 & 0.037 \\
\hline QUICK-Index & $0.33 \pm 0.03$ & $0.35 \pm 0.04$ & $0.36 \pm 0.04$ & 0.019 & 0.026 \\
\hline Total intake of carbohydrates per day (g) & $282.59 \pm 68.9$ & $248.23 \pm 91.94$ & $206.4 \pm 47.64$ & 0.17 & 0.31 \\
\hline$\%$ total Kcal as carbohydrates & $57.04 \pm 8.55$ & $53.47 \pm 9.8$ & $45.4 \pm 7.4$ & 0.038 & 0.046 \\
\hline
\end{tabular}

$\mathrm{N}$ : sample size; CPKU: classic PKU; MPKU: mild-moderate PKU; MHPA: mild hyperphenylalaninemia; y: year; TD: time of diagnosis; L: late diagnosis (by clinical symptoms or familiar history, after first month of life), E: early diagnosis (by newborn screening); Treatment: D: dietary treatment; P: pharmacological treatment; BMI: body mass index; WC: waist circumference; nor. Normal; $p^{1}: p$ value of the comparison between PKU (CPKU+MPKU) and MHPA; $p^{2}: p$ value of the comparison between CPKU, MPKU and MHPA

$p=0.0062)$. This was also the case for adults $(68.75 \%$ vs. $21.25 \%$ for BMI, $p=0.010$ and $71.9 \%$ vs. $28.1 \%$ for WC, $p=0.0011)$. BMI above the upper limit was significantly more common in patients with good rather than poor metabolic control $(68.75 \%$ vs. $31.25 \%, p=0.044)$ (Additional file 1). Moreover, a higher percentage of BMI above the upper limit was observed in PKU patients with late diagnosis and treatment $(90 \%, 9 / 10)$ when compared with those with early-diagnosis $(48.1 \%, 13 / 27)(p=0.023)$. In the control group of 68 healthy cases (age range: 449 years), 25\% (17 cases: 10 obese and 7 overweight) had a BMI above the upper limit (Additional file 2).

The mean fasting glucose level was $80.77 \pm 8.06 \mathrm{mg} / \mathrm{dL}$ (range $64-111 \mathrm{mg} / \mathrm{dL}$ ) and only one patient had high fasting glucose levels. Fasting insulin levels, with a mean of $12.74 \pm 8.4 \mathrm{mIU} / \mathrm{L}$ (range 1.8-42.5), were above upper limit in 15 PKU patients (26.3\%) and 3 MHPA patients $(11.54 \%)$ and were markedly higher in the former group ( $p=0.035)$ (Table 1). Fasting insulin levels correlated with BMI $($ rho $=0.72)$, WC $($ rho $=0.55)$, and age $($ rho $=0.463)($ Table 2$)$, and they also showed statistically significant differences according to diagnosis and Phe tolerance (Fig. 1). Mean fasting HOMA-IR for the overall group was $2.6 \pm 1.8$ (range 0.28-9.54; in children: $2 \pm 1.38$ and in adults: $3.25 \pm 2.08$ ) and, like insulin, was positively related to the same biochemical markers of carbohydrate metabolism (Table 2, Fig. 2). Conversely, patients under $\mathrm{BH} 4$ treatment had lower insulin levels $(9.9 \pm 5.4 \mathrm{mIU} / \mathrm{L}$ vs. $13.1 \pm 8.6$ $\mathrm{mIU} / \mathrm{L})$ and HOMA-IR $(1.92 \pm 1.1$ vs. $2.69 \pm 1.9)$.

Quick index was significantly lower in patients with CPKU $(0.33 \pm 0.04)$ than those with MPKU $(0.35 \pm 0.04)$ and MPHA $(0.36 \pm 0.04)(p=0.026)$ and was negatively correlated with BMI (rho $=-0.69)$, WC $($ rho $=-0.507)$, age (rho $=-0.46)$ and annual median blood Phe levels (rho $=-0.35)$. 
Table 2 Correlation (Rho) of carbohydrate metabolism markers with age, Phe tolerance, Phe anual median levels, body mass index, waist circumference and caloric intake in the form of carbohydrates in hyperphenylalaninemia patients

\begin{tabular}{|c|c|c|c|c|c|c|}
\hline & AGE (years) & Phe tolerance (mg) & $\begin{array}{l}\text { Phe median levels } \\
\text { (adequate to age) }\end{array}$ & $\begin{array}{l}\mathrm{BMl} \\
\left(\mathrm{Kg} / \mathrm{m}^{2}\right)\end{array}$ & WC $(\mathrm{cm})$ & $\begin{array}{l}\text { Caloric intake in the } \\
\text { form of carbohydrates }\end{array}$ \\
\hline $\begin{array}{l}\text { Basal Insulin } \\
\text { (mlU/L) }\end{array}$ & $\begin{array}{l}0.463 \\
p=8.5 \mathrm{e}^{-5}\end{array}$ & $\begin{array}{l}-0.164 \\
\text { n.s. }\end{array}$ & $\begin{array}{l}0.38 \\
p=0.003\end{array}$ & $\begin{array}{l}0.728 \\
p=1.5 \mathrm{e}^{-12}\end{array}$ & $\begin{array}{l}0.557 \\
p=1.4 \mathrm{e}^{-5}\end{array}$ & $\begin{array}{l}0.468 \\
p=0.006\end{array}$ \\
\hline HOMA IR & $\begin{array}{l}0.461 \\
p=9.4 e^{-5}\end{array}$ & $\begin{array}{l}-0.201 \\
\text { n.s. }\end{array}$ & $\begin{array}{l}0.353 \\
p=0.008\end{array}$ & $\begin{array}{l}0.69 \\
p=8.1 \mathrm{e}^{-11}\end{array}$ & $\begin{array}{l}0.508 \\
p=1.5 \mathrm{e}^{-4}\end{array}$ & $\begin{array}{l}0.423 \\
p=0.02\end{array}$ \\
\hline QUICKI & $\begin{array}{l}-0.461 \\
p=9.4 e^{-5}\end{array}$ & $\begin{array}{l}0.201 \\
\text { n.s. }\end{array}$ & $\begin{array}{l}-0.353 \\
p=0.008\end{array}$ & $\begin{array}{l}-0.69 \\
p=8.1 e^{-11}\end{array}$ & $\begin{array}{l}-0.508 \\
p=1.5 \mathrm{e}^{-4}\end{array}$ & $\begin{array}{l}-0.423 \\
p=0.02\end{array}$ \\
\hline Basal Fructosamine $(\mu \mathrm{M})$ & $\begin{array}{l}0.364 \\
p=0.006\end{array}$ & $\begin{array}{l}-0.041 \\
\text { n.s }\end{array}$ & $\begin{array}{l}0.152 \\
\text { n.s. }\end{array}$ & $\begin{array}{l}0.177 \\
\text { n.s. }\end{array}$ & $\begin{array}{l}0.124 \\
\text { n.s. }\end{array}$ & $\begin{array}{l}-0.011 \\
\text { n.s. }\end{array}$ \\
\hline $\begin{array}{l}\text { Basal Grelin } \\
(\mathrm{pg} / \mathrm{mL})\end{array}$ & $\begin{array}{l}-0.231 \\
\text { n.s. }\end{array}$ & $\begin{array}{l}-0.373 \\
\text { n.s. }\end{array}$ & $\begin{array}{l}-0.209 \\
\text { n.s. }\end{array}$ & $\begin{array}{l}-0.464 \\
p=0.034\end{array}$ & $\begin{array}{l}-0.348 \\
\text { n.s. }\end{array}$ & $\begin{array}{l}-0.245 \\
\text { n.s. }\end{array}$ \\
\hline $\begin{array}{l}\text { IGF1 } \\
(\mathrm{mg} / \mathrm{mL})\end{array}$ & $\begin{array}{l}0.128 \\
\text { n.s }\end{array}$ & $\begin{array}{l}0.0899 \\
\text { n.s. }\end{array}$ & $\begin{array}{l}0.087 \\
\text { n.s. }\end{array}$ & $\begin{array}{l}0.116 \\
\text { n.s. }\end{array}$ & $\begin{array}{l}0.059 \\
\text { n.s. }\end{array}$ & $\begin{array}{l}0.114 \\
\text { n.s. }\end{array}$ \\
\hline
\end{tabular}

$B M I$ body mass index, WC waist circumference, HOMA IR homeostasis model assessment insulin resistance, QUICKI quantitative insulin sensitivity check index Using a stepwise regression method based on AIC (Aikake Information Criterion), we found that the variable that most influenced insulin was BMI (linear regression model: adjusted $\mathrm{R}^{2}=0.356$; model, $\mathrm{p}-=1.591 \mathrm{e}-09$; $\mathrm{BMI}, p=1.59 \mathrm{e}-09$ ); the variable that most influenced HOMA-IR was $\mathrm{BMI}$ (linear regression model: adjusted $\mathrm{R}^{2}=0.3262$; model, $p=1.036 \mathrm{e}-08 ; \mathrm{BMI}, p=1.04 \mathrm{e}-08$ ); and the variables that most influenced BMI were phenylalanine tolerance and age (logistic regression model: null deviance $=110.674$ on 82 degrees of fredom, residual deviance $=88.154$ on 80 degrees of freedom; Phe tolerance, $p=0.00592$; age, $p=0.00642$

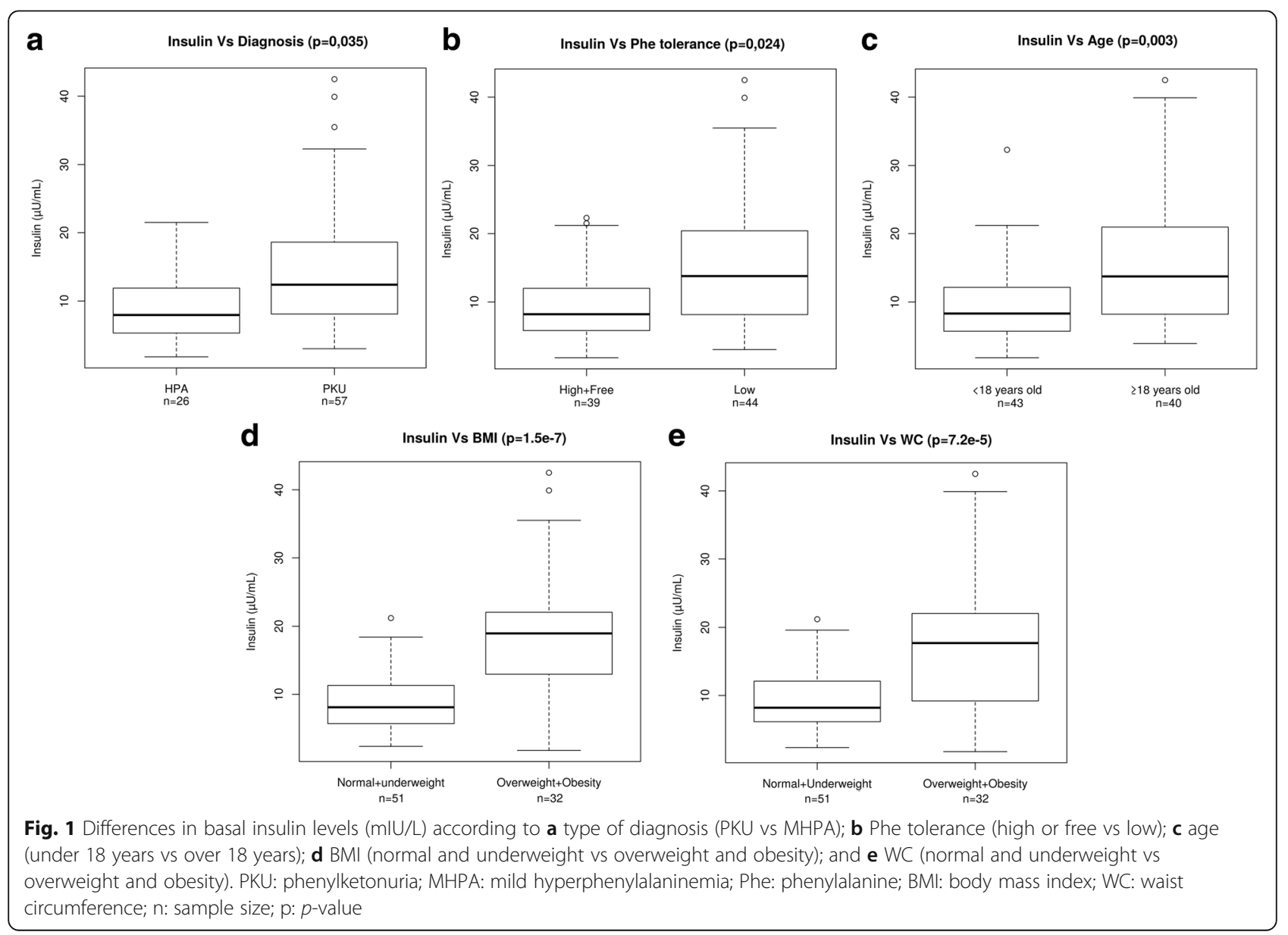




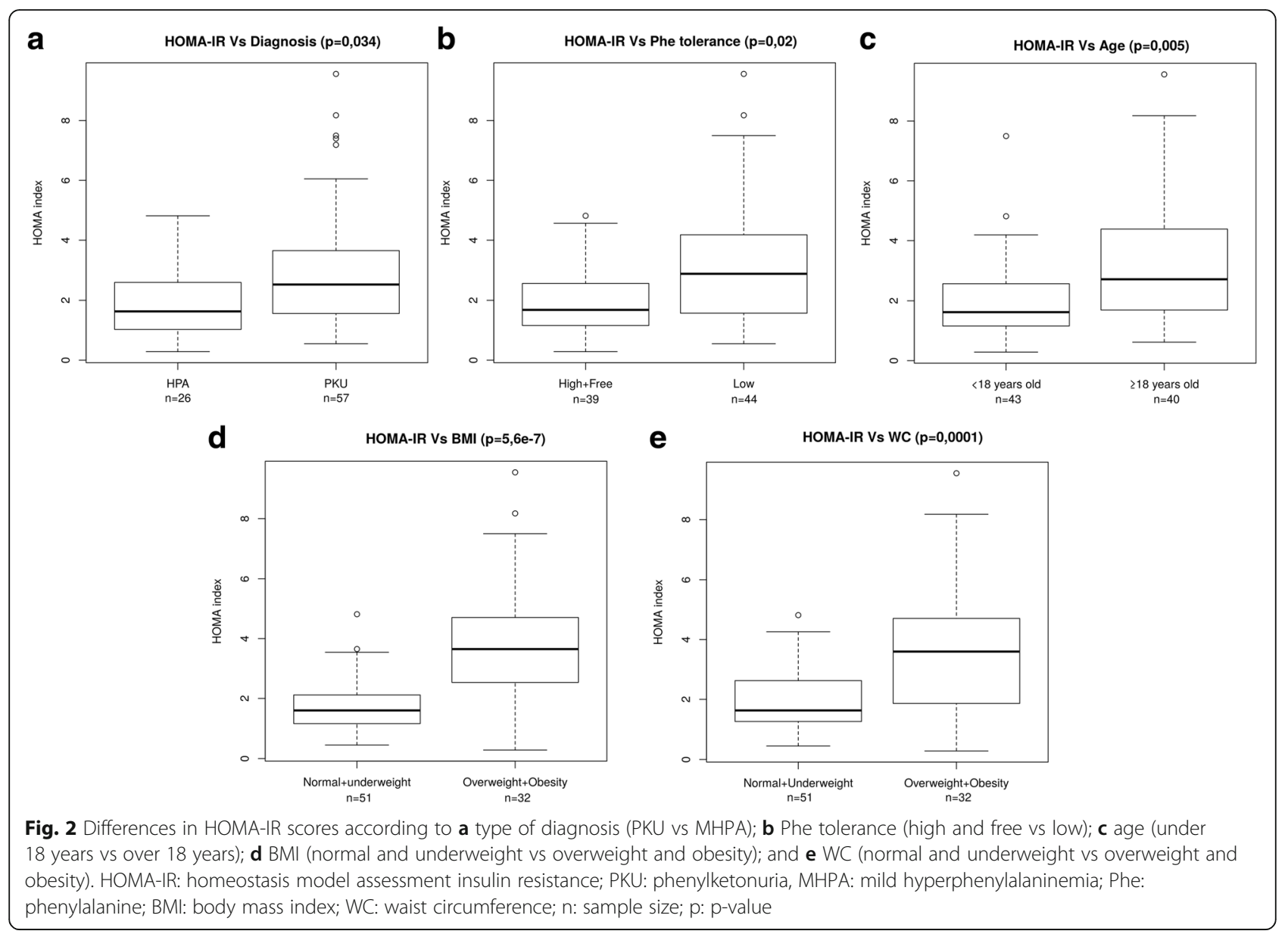

When comparing CPKU patients with early and late diagnosis, the late-diagnosis group had higher HOMA-IR values (early diagnosis: $2.97 \pm 1.88$; late diagnosis: $4.37 \pm 2.93$ ) and higher fasting insulin levels (early diagnosis: $14.69 \pm 8.7 \mathrm{mIU} / \mathrm{L}$; late diagnosis: $20.36 \pm$ $12.46 \mathrm{mIU} / \mathrm{L})$. The average concentration of HOMA-IR in control group was lower than in PKU patients $(1.65 \pm$ $1.29 ; p=0.0001)$. In overweight and obese controls (mean age: $25.46 \pm 13.77$ years, similar age than overweight and obese PKU, $p=0.72$ ): insulin and HOMA-IR concentrations also were lower in the controls (insulin: $12.63 \pm 5.87$ vs $20 \pm 9.39 \mathrm{mIU} / \mathrm{L} ; p=0.014$; Homa IR $2.86 \pm 1.37$ vs $3.95 \pm 2.17, p=0.19$ ).

Using a multiple linear regression model, we assessed the influence of each factor, and found that the variables that most influenced HOMA-IR were BMI and the percentage carbohydrate intake (linear regression model: $\mathrm{R}^{2}$ adjusted $=0.352 ; p$ value of the model $=1.7 \mathrm{e}^{-5} ; \mathrm{p}$ value $\mathrm{BMI}=0.0005 ; \mathrm{p}$ value $\%$ carbohydrates $=0.033$ ).

Lactate, C-peptide, IGFBP3, and urea levels were normal in the vast majority of patients. IGF1 levels were elevated in 21 patients $(206.6 \pm 92.4 \mathrm{mg} / \mathrm{mL})$.Basal ghrelin was high in 28 patients $(868.6 \pm 453.1 \mathrm{pg} / \mathrm{mL})$ and was negatively correlated with BMI $($ rho $=-0.46)$. Fructosamine levels were within normal ranges in 93.98\% of patients, but mean levels were significantly higher in adults $(239 \pm 44 \mu \mathrm{mol} / \mathrm{L}$ vs. $223.6 \pm 26 \mu \mathrm{mol} / \mathrm{L}$, $p=0.010$ ).

Caloric intake in the form of carbohydrates was significantly higher in PKU than MHPA patients $(p=0.038)$. It was also positively correlated with basal insulin (rho $=0.47, p=0.006$ ) and HOMA-IR $($ rho $=0.42, p=0.02)$ (Table 2$)$. Mean daily carbohydrate intake from AA mixtures was $53.71 \pm 9.6 \mathrm{~g}$ (range 30-70 g), being higher in CPKU (57.042 \pm $8.5 \mathrm{~g})$ than in MPKU patients $(53.47 \pm 9.8 \mathrm{~g})$. As expected, ingestion of AA mixture led to a marked increase in insulin levels (basal levels: $14.44 \pm 9$ vs. postprandial levels $37.62 \pm 38.4, p=1.4 \mathrm{e}^{-7}$ ) and HOMA-IR scores $\left(2.9 \pm 2\right.$ vs. $\left.8.8 \pm 12.5, p=1 \mathrm{e}^{-7}\right)$ (Fig. 3). No significant differences were observed for pre- and postprandial fructosamine levels, although ghrelin levels decreased significantly $(814.4 \pm 416.6$ vs. $664.2 \pm 379.2$; $p=0.0002$, Fig. 3 ). 


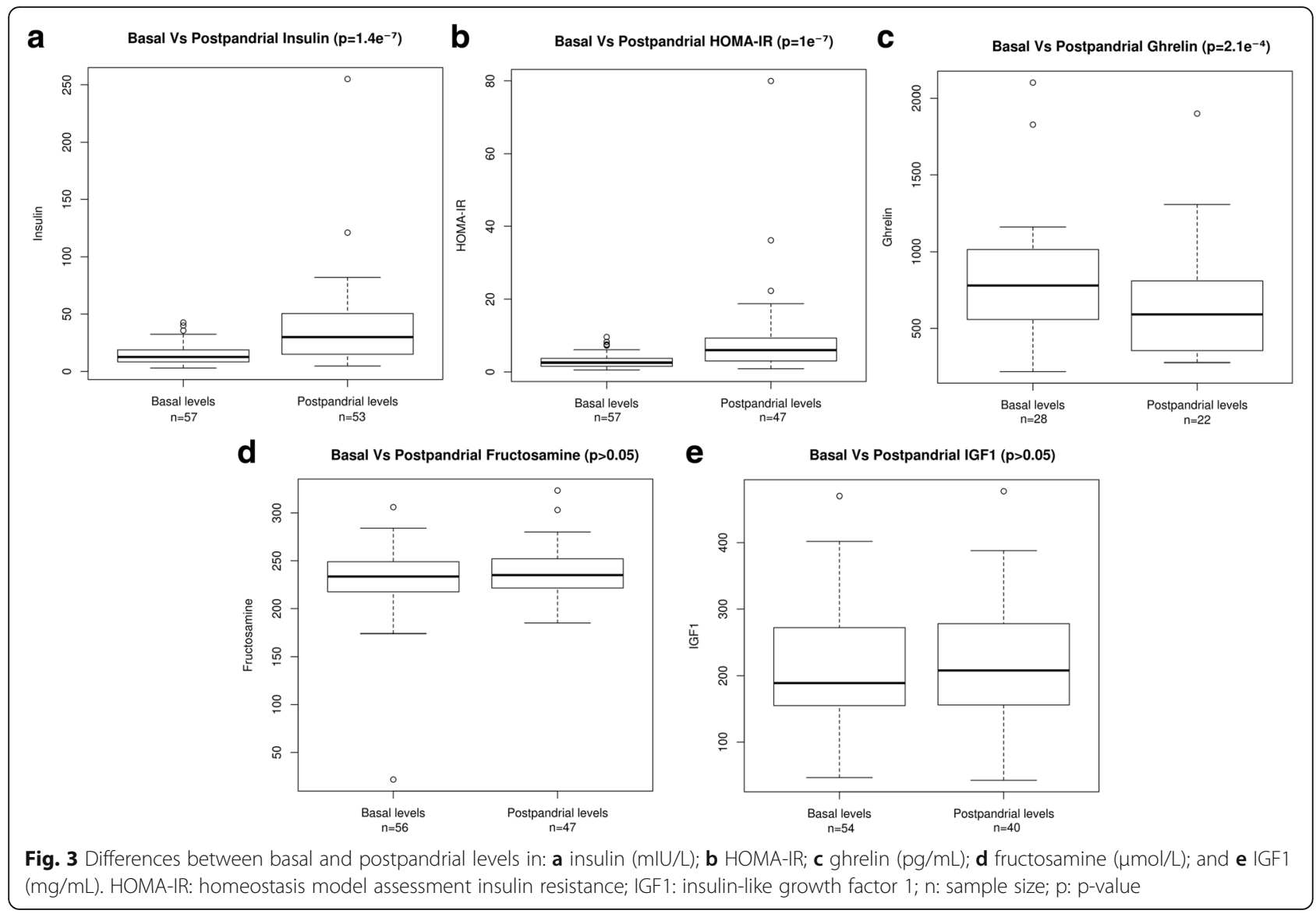

\section{Discussion}

To gain better insights into the metabolic impact of high carbohydrate intake in patients with PKU, we compared carbohydrate metabolism between patients receiving dietary treatment only or dietary and pharmacological treatment for PKU and patients with MPHA on a free diet without excessive intake of proteins of high biological value.

The normal fasting glucose levels found in the majority of patients with PKU were in good agreement with previous findings [14, 17]. However, we observed increased rates of insulin resistance, with higher levels of basal insulin and HOMA-IR in PKU patients, associated with age, BMI, and $\mathrm{WC}$, suggesting possible alterations in glucose homeostasis. This positive correlation between insulin resistance (HOMA-IR) and WC is in line with the findings of Kanufre et al. [16] in children and adolescents with PKU and excess weight. Insulin resistance and basic $\beta$-cell dysfunction are primary features of fasting hyperglycemia. A high HOMA index has been associated with an increased prevalence of carbohydrate intolerance and diabetes in obese and non-obese individuals from different ethnic backgrounds [32-35].
Although insulin resistance standards have not been established for the pediatric population [36], mean HOMA-IR in children with PKU in our series (mean \pm SD: $\quad 2.23 \pm 1.51 ; \quad$ median (Q1-Q3):1.78(1.47,2.73)was higher than that of pediatric healthy controls $(1.57 \pm$ 1.09 ; in < 7.5 years: $0.61 \pm 0.37$; in $>7.5$ years: $1.84 \pm$ $1.07)$ and also higher than values reported for the general pediatric population $(0.6[0.3-1.4]$ for prepubertal children aged $<7.5$ years, $1.1[0.3-2]$ for those aged $>$ 7.5 years and 1.4 [0.3-2.5] for pubertal adolescents [37]) and for children and adolescents with PKU (median \pm SD: $0.9 \pm 0.4$ [14] and $0.7 \pm 1.1$ in patients with normal weight [15]). However, comparison with PKU series is difficult since the age of the pediatric patients included varies, ranging from 5 to 11 years [14], 4-15 years [15], and up to 18 years in our study.

The same trend was observed for PKU adults, for whom mean HOMA-IR $(3.45 \pm 2.19)$ was higher than that of our adult controls $(1.79 \pm 1.57)$ and that reported for the general population in southeast and northeast Spain (1.7 [38] and 1.72 [39], respectively).

HOMA-IR has been independently associated with an increased risk of hypertension [40], and, according to a meta-analysis of 65 studies, this index, together with 
fasting glucose and insulin levels, is linked to incident cardiovascular disease in individuals without diabetes (46\% increase in coronary heart disease risk for an increase of one standard deviation in HOMA-IR) [41].

As previously noted, increased insulin resistance in PKU patients under dietary treatment could be related to metabolic changes caused by long-term intake of high levels of carbohydrate. The deleterious effects of high free sugar-free intake appear to be more evident when this is accompanied by excess energy intake [42]. On average carbohydrates accounted for $35.58 \%$ of the total energy content of AA mixtures. This result is in accordance with the data published by Moretti F et al. [14] in a series of PKU children in which Phe-free protein substitutes and special low-protein products accounted for more than $60 \%$ of overall daily energy, protein and carbohydrate intake. One limitation of our study is that we were unable to analyze total sugar free intake in PKU patients under dietary treatment as this information is not widely available for the formulas marketed in Spain. According to the Scientific Advisory Committee on $\mathrm{Nu}-$ trition recommendations on carbohydrates, free sugars should account for no more than $5 \%$ of daily dietary energy intake [43].

Insulin resistance is a marker of metabolic syndrome $[44,45]$ and, while according to the criteria of the American Diabetes Association, it has not yet been linked to pathological glucose levels [46] (with the exception of one case), one could speculate that in the absence of dietary intervention, impaired glucose tolerance could develop at an early age. In our series, insulin resistance was more patent in adults and, coinciding with previous findings [15] in overweight patients.

Although some findings suggest that patients with PKU have similar rates of overweight and obesity to individuals without this disorder [47], a clear tendency towards overweight and obesity (based on BMI) in patients with PKU has also been reported [48-51]. The percentage of overweight/obese subjects in our control group (25\%) is similar to that reported for the general population (26.7\%) [52]. In our cohort, the percentage of overweight/obese in PKU patients is higher than in HPA $(p=0.0062)$ and healthy controls $(p=0.042)$, especially in those with late diagnosis, probably reflecting poor dietary and exercise habits. However, after adjusting using a logistic regression model, with $\mathrm{BMI}$ as the response variable (groups: normal and overweight + obese) and age and diagnosis (groups: PKU and HPA) as explanatory variables, we found that age had the greatest effect on BMI, and that the type of diagnosis alone had no significant effect (age, $p=0.0055$; type of diagnosis, $p=0.0560$ ). Thus, the increased insulin resistance in PKU is likely multifactorial, and particularly influenced by factors such as age, BMI, and dietary carbohydrate intake.
Ghrelin is a growth-hormone-releasing acylated peptide that has been found to enhance appetite [53]. In a study by Weigel et al. [54], 70\% of patients with PKU experienced a mean reduction in ghrelin levels of $18.5 \%$ (range, 2.2-33\%) after ingestion of an AA mixture containing carbohydrate. Although conflicting results have been reported by previous studies of ghrelin in patients with different diseases associated with obesity, our detection of a group of patients with increased basal and postprandial ghrelin levels suggests that homeostatic appetite control mechanisms may be altered in certain cases of PKU, possibly in relation to the nutritional profile of the dietary product prescribed. Although this hypothesis needs to be tested in specifically designed studies, we can speculate that dietary changes might alter the physiological mechanisms of appetite control in certain patients, leading to an increase in central adiposity and insulin resistance.

\section{Conclusions}

Insulin resistance was increased in PKU patients and was particularly evident in adults and in overweight or obese patients. A higher consumption of AA mixture, and a higher caloric intake in the form of carbohydrates, this one positively correlated with fasting insulin and HOMA-IR, was observed in PKU patients, and thus could contribute to carbohydrate intolerance.

\section{Additional files}

Additional file 1: Clinical and basal biochemical characteristics of each patient with hyperphenylalaninemia. (DOCX $48 \mathrm{~kb}$ )

Additional file 2: Clinical and biochemical characteristics of healthy controls. (DOCX $21 \mathrm{~kb}$ )

\section{Abbreviations}

BMI: Body mass index; CPKU: Classic phenylketonuria; HOMA-IR: Homeostasis Model Assessment Insulin Resistance; IGF1: Insulin-like growth factor 1;

IGFBP3: IGF-binding protein 3; LNAA: Large neutral amino acids; MHPA: Mild hyper-Phe; MPKU: Mild-moderate PKU; Phe: Phenylalanine;

PKU: Phenylketonuria; WC: Waist circumference

\section{Acknowledgements}

We thank all patients and their families for kindly participating in the study.

\section{Funding}

Article-processing charge was covered by the Fundación IDIS-C012.

\section{Availability of data and materials}

The dataset supporting the conclusions of this article is included within the article and its additional file.

\section{Authors' contributions}

MLC, PSP, AH, MMO and RL reviewed the literature and conceived the study. IV, MJC, PC, LAE were involved in patient selection, monitoring and data collection. IR, AFM, RL, FA interpreted the results, drafted the manuscript and were involved in the statistical analysis. AFM, IR, PSP and MLC reviewed and edited the manuscript. All authors critically revised the manuscript and approved the final version. 


\section{Ethics approval and consent to participate}

The study protocol was approved by the Research Ethics Committee of Santiago-Lugo (2016/470).

\section{Consent for publication}

Consent to publish was obtained from the people and / or relatives who participated in the study.

\section{Competing interests}

The authors declare that they have no competing interests.

\section{Publisher's Note}

Springer Nature remains neutral with regard to jurisdictional claims in published maps and institutional affiliations.

\section{Author details}

${ }^{1}$ Unit of Diagnosis and Treatment of Congenital Metabolic Diseases, S. Neonatology, Department of Pediatrics, Hospital Clínico Universitario de Santiago de Compostela, CIBERER, Health Research Institute of Santiago de Compostela (IDIS), A Choupana, s/n, 15706 Santiago de Compostela, A Coruña, Spain. ${ }^{2}$ Unit of Metabolopathies, Hospital Universitario la Fe, Bulevar sur s/n, 46021 Valencia, Spain. ${ }^{3}$ Unit of Metabolism, Department of Pediatrics, Hospital de Cruces. Group of Metabolism, Biocruces Health Research Institute, CIBERER, Plaza de Cruces s/n, 48903 Barakaldo, Vizcaya, Spain. ${ }^{4} U n i t$ of Gastroenterology and Nutrition, Department of Pediatrics, Hospital Clinico Universitario de Santiago, IDIS, Travesía da Choupana s/n,15706 Santiago de Compostela, A Coruña, Spain.

Received: 26 February 2018 Accepted: 20 June 2018

Published online: 27 June 2018

\section{References}

1. Blau N, van Spronsen FJ, Levy HL. Phenylketonuria. Lancet. 2010;376:1417-27.

2. Bóveda MD, Couce ML, Castiñeiras DE, Cocho JA, Pérez B, Ugarte M, Fraga $\mathrm{JM}$. The tetrahydrobiopterin loading test in 36 patients with

hyperphenylalaninaemia: evaluation of response and subsequent treatment. J Inherit Metab Dis. 2007:30:8-12.

3. Burlina A, Blau N. Effect of BH(4) supplementation on phenylalanine tolerance. J Inherit Metab Dis. 2009:32:40-5.

4. Trefz FK, Burton BK, Longo N, Casanova MM, Gruskin DJ, Dorenbaum A, Kakkis ED, Crombez EA, Grange DK, Harmatz P, Lipson MH, Milanowski A, Randolph LM, Vockley J, Whitley CB, Wolff JA, Bebchuk J, Christ-Schmidt H, Hennermann JB. Efficacy of sapropterin dihydrochloride in increasing phenylalanine tolerance in children with phenylketonuria: a phase III, randomized, doubleblind, placebo-controlled study. J Pediatr. 2009;154:700-7.

5. Giovannini M, Verduci E, Salvatici E, Paci S, Riva E. Phenylketonuria: nutritional advances and challenges. Nutr Metab. 2012;9(1):7.

6. Yi S, Singh $\mathrm{RH}$. Protein substitute for children and adults with phenylketonuria. Cochrane Database Syst Rev. 2008;4:CD004731.

7. Mirás A, Bóveda MD, Leis MR, A. Mera A, Aldámiz-Echevarría, L, FernándezLorenzo JR, Fraga JM, Couce ML. Risk factors for developing mineral bone disease in phenylketonuric patients. Mol Genet Metab 2013; 108:149-154.

8. Crujeiras V, Aldámiz-Echevarría L, Dalmau J, Vitoria I, Andrade F, Roca I, Leis $R$, Fernandez-Marmiesse A, Couce ML. Vitamin and mineral status in patients with hyperphenylalaninemia. Mol Genet Metab. 2015;115:145-50.

9. Evans S, Daly A, MacDonald J, Preece MA, Santra S, Vijay S, Chakrapani A, MacDonald $A$. The micronutrient status of patients with phenylketonuria on dietary treatment: an ongoing challenge. Ann Nutr Metab. 2014;65:42-8.

10. Rocha JC, van Rijn M, van Dam E, Ahring K, Bélanger-Quintana A, Dokoupil K, Gokmen Ozel H, Lammardo AM, Robert M, Heidenborg C, MacDonald A. Weight management in phenylketonuria: what should be monitored. Ann Nutr Metab 2016. 68:60-5.

11. Pena MJ, de Almeida MF, van Dam E, Ahring K, Bélanger-Quintana DK Gokmen-Ozel H, Lammardo AM, MacDonald A, Robert M, Rocha JC. Protein substitutes for phenylketonuria in Europe: access and nutritional composition. Eur J Clin Nutr. 2016:70:785-9.

12. Acosta PB, Yannicelli S, Singh RH, Elsas LJ, Mofidi S, Steiner RD. Iron status of children with phenylketonuria undergoing nutrition therapy assessed by transferring receptors. Genet Med. 2004;6:96-101.

13. Couce ML, Vitoria I, Aldámiz-Echevarría L, Fernández-Marmiesse A, Roca I, Llarena M, Sánchez-Pintos P, Leis R, Hermida A. Lipid profile status and other related factors in patients with Hyperphenylalaninaemia. Orphanet J Rare Dis. 2016:11:123.

14. Moretti F, Pellegrini N, Salvatici E, Rovelli V, Banderali G, Radaelli G, Scazzina F, Giovannini M, Verduci E. Dietary glycemic index, glycemic load and metabolic profile in children with phenylketonuria. Nutr Metab Cardiovasc Dis. 2017:27:176-82

15. Kanufre VC, Soares RD, Alves MR, Aguiar MJ, Starling AL, Norton RC. Metabolic syndrome in children and adolescents with phenylketonuria. J Pediatr. 2015;91:98-103.

16. Verduci E, Banderali G, Moretti F, Lassandro C, Cefalo G, Radaelli G, Salvatici E, Giovannini M. Diet in children with phenylketonuria and risk of cardiovascular disease: a narrative overview. Nutr Metab Cardiovasc Dis. 2016:26:171-7.

17. Stewart RM, Hemli S, Kolodny EH, Miller AL, Pallotta JA. Carbohydrate metabolism in phenylketonuria. Pediatr Res. 1980;14:849-53.

18. Güttler F, Kühl C, Pedersen L, Påby P. Effects of oral phenylalanine load on plasma glucagon, insulin, amino acid and glucose concentrations in man. Scand J Clin Lab Invest. 1978;38:255-60.

19. Vockley J, Andersson HC, Antshel KM, Braverman NE, Burton BK, Frazier DM, Mitchell J, Smith WE, Thompson BH, Berry SA. American College of Medical Genetics and Genomics. Therapeutics committee, phenylalanine hydroxylase deficiency: diagnosis and management guideline. Genet Med. 2014;16:188-200.

20. Campistol J, Lambruschini N, Castejón E, Gutierrez A, Fusté E, Gassió R, Vilaseca MA. Hiperfenilalaninemia. In: sanjurjo P, Baldellou A, editors. Diagnóstico y Tratamiento de las Enfermedades Metabólicas Hereditarias. 4aed ed. Madrid: Ergón; 2014. p. 455-77.

21. van Spronsen FJ, van Wegberg AM, Ahring K, Bélanger-Quintana A, Blau N, Bosch AM, Burlina A, Campistol J, Feillet F, Giżewska M, Huijbregts SC, Kearney S, Leuzzi V, Maillot F, Muntau AC, Trefz FK, van Rijn M, Walter JH, MacDonald A. Key European guidelines for the diagnosis and management of patients with phenylketonuria. Lancet Diabetes Endocrinol. 2017;5:743-56.

22. Martínez-Pardo M, Marchante C, Dalmau J, Pérez M, Bellón C. Protocolo de diagnóstico, tratamiento y seguimiento de las hiperfenilalaninemias. An Esp Pediatr. 1998;114:3-18.

23. Acosta PB, Yannicelli S, Singh R, Mofidi S, Steiner R, De Vincentis E, Jurecki E, Bernstein L, Gleason S, Chetty M, Rouse B. Nutrient intakes and physical growth of children with phenylketonuria undergoing nutrition therapy. J Am Diet Assoc. 2003;103:1167-73.

24. WHO. Physical status: the use and interpretation of anthropometry. Report of a WHO expert committee. World Health Organ Tech Rep Ser. 1995:854:1-452.

25. WHO Multicentre Growth Reference Study Group. WHO child growth standards based on length/height, weight and age. Acta Paediatr. 2006:450:S76-85.

26. Tojo Sierra R, Leis Trabazo R. Estudio Galinut. In: Valores Estandar de Galicia. Santiago de Compostela: Universidad de Santiago de Compostela; 1999.

27. Zimmet $P$, Alberti G, Shaw J. Nueva definición mundial de la IDF del Síndrome metabólico. Diabetes Voice. 2005:50:31-3.

28. Matthews DR, Hosker JP, Rudenski AS, Naylor BA, Treacher DF, Turner C. Homeostasis model assessment: insulin resistance and beta-cell function from fasting plasma glucose and insulin concentrations in man. Diabetologia. 1985:28:412-9.

29. Mojiminiyi OA, Abdella NA. Effect of homeostasis model assessment computational method on the definition and associations of insulin resistance. Clin Chem Lab Med. 2010;48:1629-34.

30. Katz A, Nambi SS, Mather K, Baron AD, Follmann DA, Sullivan G, Quon MJ. Quantitative insulin sensitivity check index: a simple, accurate method for assessing insulin sensitivity in humans. J Clin Endocrinol Metab. 2000;85:2402-10.

31. R Core Team. R: a language and environment for statistical computing. In: R Foundation for Statistical Computing. Vienna, Austria; 2017. URL https:// www.R-project.org/.

32. Haffner SM, Miettinen $\mathrm{H}$, Stern MP. The homeostasis model in the San Antonio heart study. Diabetes Care. 1997:20:1087-92.

33. Matsumoto K, Miyake S, Yano M, Ueki Y, Yamaguchi Y, Akazawa S, Tominaga Y. Glucose tolerance, insulin secretion, and insulin sensitivity in nonobese and obese Japanese subjects. Diabetes Care. 1997;20:1562-8.

34. Dubinina IA, Chistiakov DA, Eremina IA, Brovkin AN, Zilberman LI, Nikitin AG, Kuraeva TL, Nosikov W, Peterkova VA, Dedov II. Studying progression from glucose intolerance to type 2 diabetes in obese children. Diabetes Metab Syndr. 2014;8:133-7. 
35. Pratyush DD, Tiwari S, Singh S, Singh SK. Risk factors of diabetes in north Indians with metabolic Sndrome. Diabetes Metab Syndr. 2016;10:S68-71.

36. Levy-Marchal C, Arslanian S, Cutfield W, Sinaiko A, Druet C, Loredana M, Chiarelli F, On behalf of ESPE-LWPES-ISPAD-APPES-APEG-SLEP-JSPE, and the insulin resistance in children consensus conference group. Insulin resistance in children: consensus, perspective. J Clin Endocrinol Metab. 2010;95:5189-98.

37. Ballerini MG, Bergadá I, Rodríguez ME, Kaselman A, Bengolea VS, Pipman V, Domené HM, Jasper HG, Ropelato MG. Insulin level and insulin sensitivity índices among healthy children and adolescents. Arch Argent Pediatr. 2016; 114:329-36.

38. Rojo-Martínez G, Esteva I, de Adana SR, Catalá M, Merelo MJ, Tinahones F, Gómez-Zumaquero JM, Cuesta AL, Cardona F, Soriguer F. Patterns of insulin resistance in the general population of Southeast Spain. Diabetes Res Clin Pract. 2004;65:247-56.

39. Tomé M, Botana M, Cadarso-Suárez C, Rego-Iraeta A, Fernández-Mariño A, Mato JA, Solache I, Perez-Fernandez R. Prevalence of metabolic syndrome in Galicia (NW Spain) on four alternative definitions and association with insulin resistance. J Endocrinol Investig. 2009;32:505-11.

40. Wang F, Han L, Hu D. Fasting insulin, insulin resistance and risk of hypertension in the general population: a meta-analysis. Clin Chim Acta. 2017:464:57-63.

41. Gast KB, Tjeerdema N, Stijnen T, Smit JW, Dekkers OM. Insulin resistance and risk of incident cardiovascular events in adults without diabetes: metaanalysis. PLoS One. 2012;7:e52036.

42. Macdonald IA. A review of recent evidence relating to sugars, insulin resistance and diabetes. Eur J Nutr. 2016:55:517-23.

43. SACN. Carbohydrates and Health. Published for Public Health England under licence from the controller of her majesty's stationery Office 2015. ISBN: 9780117082847

44. Balkau B, Charles MA. Comment of the provisional report from WHO consultation. European Group for de study of insulin resistance (EGIR) Diabet Med. 1999;16:442-3.

45. World Health Organization. Definition, diagnosis and classification of diabetes mellitus and its complications. Report of a WHO consultation. In: Geneve: WHO; 1999.

46. American Diabetes Association. Classification and diagnosis of diabetes. Diabetes Care. 2017:40:511-24.

47. Rocha JC, van Spronsen FJ, Almeida MF, Soares G, Quelhas D, Ramos E, Guimarães JT, Borges N. Dietary treatment in phenylketonuria does not lead to increased risk of obesity or metabolic syndrome. Mol Genet Metab. 2012; 107:659-63.

48. Aldámiz-Echevarría L, Bueno MA, Couce ML, Lage S, Dalmau J, Vitoria I, Andrade F, Blasco J, Alcalde C, Gil D, García MC, González-Lamuño D, Ruiz M, Peña-Quintana L, Ruiz MA, González D, Sánchez-Valverde F. Anthropometric characteristics and nutrition in a cohort of PAH-deficient patients. Clin Nutr. 2014;33:702-17.

49. Dokoupil K, Gokmen-Ozel H, Lammardo AM, Motzfeldt K, Robert M, Rocha JC, van Rijn M, Ahring K, Bélanger-Quintana A, MacDonald A. Optimising growth in phenylketonuria: current state of the clinical evidence base. Clin Nutr. 2012:31:16-21.

50. Giovannini M, Verduci E, Salvatici E, Fiori L, Riva E. Phenylketonuria: dietary and therapeutic challenges. J Inherit Metab Dis. 2006;30:145-52.

51. Scaglioni S, Verduci E, Fiori L, Lammardo AM, Si R, Radaelli G, Riva E, Giovannini M. Body mass index rebound and overweight at 8 years of age in hyperphenylalaninaemic children. Acta Paediatr. 2004;93:1596-600.

52. Overweight and obesity and their impact on health. Global Status Report on noncommunicable diseases 2014. World Health Organization (WHO).

53. Wren AM, Seal LJ, Cohen MA, Brynes AE, Frost GS, Murphy KG. Ghrelin enhances appetite and increases food intake in humans. J Clin Endocrinol Metab. 2001;86:5992.

54. Weigel C, Rauh M, Kiener C, Eascher W, Kner I. Effects of various dietary amino acid preparations for phenylketonuric patients on the metabolic profiles along with postprandial insulin an ghrelin responses. Ann Nutr Metab. 2007;51:352-8.

\section{Ready to submit your research? Choose BMC and benefit from:}

- fast, convenient online submission

- thorough peer review by experienced researchers in your field

- rapid publication on acceptance

- support for research data, including large and complex data types

- gold Open Access which fosters wider collaboration and increased citations

- maximum visibility for your research: over $100 \mathrm{M}$ website views per year

At BMC, research is always in progress.

Learn more biomedcentral.com/submissions 